\title{
Investigation of Antimicrobial Activity of 1,3-benzoxazine Derivatives
}

\author{
S. P. Zahorulko1, S. A. Varenichenko ${ }^{1}$, O. K. Farat ${ }^{2}$, I. V. Markova ${ }^{3}$, V. I. Markov ${ }^{1}$ \\ ${ }^{1}$ Ukrainian State University of Chemical Technology \\ 8 Gagarina Ave., Dnipro, Ukraine, 49005 \\ ${ }^{2}$ M. V. Lomonosov Moscow State University \\ Leninskie Gory, 1/12, Moscow, Russian Federation, 119991 \\ ${ }^{3}$ Dnipro National University of Railway Transport named after V. Lazaryana \\ 2, Lazaryan Str., Dnipro, Ukraine, 49010 \\ svetlanavarenichenko@gmail.com
}

\begin{abstract}
Aim. To investigate potential antimicrobial activity of 1,3-benzoxazines derivatives. Methods. Synthesis, antimicrobial screening, antimicrobial and antifungal activity testing in vitro. Results. For antimicrobial screening, we chose the compounds that differed from the investigated ones by $30 \%$. Five compounds were selected and their antimicrobial activity against five bacterium and two fungus strains was studied by the methods of microbial growth inhibition assay. The percentage of growth inhibition of an individual sample is calculated considering a negative control (media only) and a positive control (bacterial / fungal media without inhibitors). The results obtained showed that compounds 2-[5-(4-nitrophenyl)- $1 H$-pyrazol-3-yl]phenol and 6,8-diisopropylspiro[1,3benzoxazine-2,1'-cyclohexan]-4(3H)-one in concentration of $32 \mu \mathrm{g} / \mathrm{ml}$ have the highest activity against Acinetobacter baumannii - $43 \%$ and $27 \%$, respectively. The compound, 6,8-diisopropyl2-methyl-2-(4-nitrophenyl)-2,3-dihydro-4H-1,3-benzoxazine-4-one showed the fungicidal activity against the Candida albicans strain. Conclusion. The derivatives of 1,3-benzoxazines exhibit a moderate antimicrobial activity, which allows the recommendation to continue the search for effective antimicrobials among the chemical compounds of this group, in particular, through the targeted synthesis of new compounds with predicted antimicrobial properties.
\end{abstract}

Ke y w or d s: 1,3-benzoxazines, $1 H$-pyrazol-3-yl-phenol, antimicrobial screening

\section{Introduction}

Today, the problem of finding new effective medicines remains topical, despite the fact that branded medicines of various pharmacological groups are widely represented in the modern pharmaceutical market. One of the promising classes of chemical compounds, from the point of view of obtaining new biologically active substances on their basis, is the derivatives of benzoxazines. Professional journals quite often publish new information about the possibilities

(C) 2019 S. P. Zahorulko et al.; Published by the Institute of Molecular Biology and Genetics, NAS of Ukraine on behalf of Biopolymers and Cell. This is an Open Access article distributed under the terms of the Creative Commons Attribution License (http://creativecommons.org/licenses/by/4.0/), which permits unrestricted reuse, distribution, and reproduction in any medium, provided the original work is properly cited 
of pharmacological application of the derivatives of compounds of this class. Benzoxazines are reported to be used as th potent progesterone receptor agonists, DNA-binding antitumor agents, human leukocyte elastase (HLE) and Clr serine protease inhibitors, as well as the fungicidal, anti-inflammatory and anticonvulsant drugs [1]. The derivatives of 1,4-benzoxazine exhibit the inhibitory activity in cell proliferation, which impedes the endothelial cell migration, and inhibition of angiogenesis in the chorioallantoic membrane assay [2]. Among the derivatives of 1,2-dihydrobenzoxazines, some promising compounds with biological activity have also been identified [3-5]. In particular, the study of 6-aryl-1,2dihydro-4H-3,1-benzoxazine and 6-aryl-1,2dihydro-4H-3,1-benzoxazine-2-thione has led to the development of potent and selective nonsteroidal progesterone-receptor agonists. Acridines with 1,2-dihydrobenzoxazines have demonstrated the cytotoxic activity against some lines of human cancer. The benzoxazine fragments are often found in natural compounds. For example, four alkaloids with antimicrobial action have been allocated from the sea sponge Jaspis splendans. One of them contains a substituent of the benzoxazine type [6]. High practical significance has prompted us to investigate the antimicrobial activity of 1,3-benzoxazines derivatives.

\section{Materials and Methods}

\section{Methodology for the research] of the antibacterial activity}

All bacteria were cultured in Cation-Adjusted Mueller-Hinton Broth (CAMHB) at $37{ }^{\circ} \mathrm{C}$ overnight. Each sample was diluted 40 times in a fresh medium and then, incubated at $37^{\circ} \mathrm{C}$ for 1.5-3 hours. The samples of the mean logarithmic phase were diluted $\left(4.5-5 \times 10^{5} \mathrm{CFU} /\right.$ $\mathrm{ml}$, measured by $600 \mathrm{~nm}(\mathrm{OD} 600))$. Then, the compounds containing the plates were added to each well, yielding a cell density of $5 \times 10^{5}$ $\mathrm{CFU} / \mathrm{ml}$ and a total volume of $50 \mu \mathrm{l}$. All plates were coated and incubated at $37{ }^{\circ} \mathrm{C}$ for 18 hours without shaking.

Inhibition of growth of all bacteria was determined measuring absorbance at $600 \mathrm{~nm}$ (OD600), using a Tecan M1000 Pro monochromator plate reader. The percentage of growth inhibition was calculated for each well, using the negative control (media only) and positive control (bacteria without inhibitors) on the same plate as reference.

\section{Methodology of research of the antifun- gal activity}

The fungi strain was cultivated for 3 days on YPD at $30{ }^{\circ} \mathrm{C}$. A suspension of yeast from $1 \times 10^{6}$ to $5 \times 10^{6} \mathrm{CFU} / \mathrm{ml}$ (as defined by OD530) was prepared from five colonies. The suspension was then diluted and added to each well of the plates containing the compound, which gave the final density of fungi cells suspension of $2.5 \times 10^{3} \mathrm{CFU} / \mathrm{ml}$ and a total volume of $50 \mu$ l. All plates were coated and incubated at $35{ }^{\circ} \mathrm{C}$ for 36 hours without shaking.

The growth inhibition of $C$. albicans was determined measuring absorbance at $530 \mathrm{~nm}$ (OD530). The growth inhibition of $C$. neoformans was determined measuring the difference in absorbance between 600 and $570 \mathrm{~nm}$ (OD600-570), after the addition of resazurin $(0.001 \%$ final concentration) and incubation at $35^{\circ} \mathrm{C}$ for additional 2 hours. The absorbance 
was measured using Biotek Synergy HTX Microplate Reader. The percentage of growth inhibition was calculated for each well, using negative control (media only) and positive control (fungi without inhibitors) on one plate.

The percentage [of] growth inhibition of an individual sample is calculated based on negative controls (media only) and positive controls (bacterial / fungal media without inhibitors). The negative inhibition values indicate that the growth rate (or OD600) is higher compared to the negative control (bacteria / fungi only set to $0 \%$ inhibition). The growth rate for all bacteria and fungi has a variation of $+10 \%$, which is within the reported normal distribution of bacterial / fungal growth.

\section{Results and Discussion}

The methods of synthesis of geminal 1,3-benzoxazines derivatives had been developed in the previous studies authors. The Derivatives of 1,3-benzoxazines (1-4) have been obtained through the interaction of substituted salicylamides with ketones in benzene in the presence of $\mathrm{p}-\mathrm{TsOH}$ removing water with a DeanStark trap (Scheme 1) [11, 12].

The 2-[5-(4-Nitrophenyl)-1H-pyrazol-3-yl] phenol (5) (Scheme 2) was obtained in the reaction of 2-(4-nitrophenyl)-4H-chromen-4imine with hydrazine hydrate [12].

In cooperation with the Institute of Molecular Biology and Genetics of the National Academy of Sciences of Ukraine, we sampled the synthesized compounds. These compounds were compared with the compounds whose antimicrobial activity had already been investigated (CHEMBL [13] and DrugBank [14] databases.) For antimicrobial screening, we chose the compounds that differed from the investigated ones by $30 \%$. Five compounds were selected and their antimicrobial activity against five bacterium and two<smiles>[R]c1cc([R])c(O)c(C(N)=O)c1</smiles>

1-4<smiles>N=c1cc(-c2ccc([N+](=O)[O-])cc2)oc2ccccc12</smiles><smiles>O=[N+]([O-])c1ccc(-c2cc(-c3ccccc3O)n[nH]2)cc1</smiles>

$1-\mathrm{R}=\mathrm{i}-\mathrm{Pr}, \mathrm{R} 1=\mathrm{R} 2=\left(\mathrm{CH}_{2}\right)_{4} ; 2-\mathrm{R}=\mathrm{H}$, $\mathrm{R} 1=\mathrm{CH}_{3}, \mathrm{R} 2=4-\mathrm{NO}_{2}-\mathrm{C}_{6} \mathrm{H}_{4} ; 3-\mathrm{R}=\mathrm{i}-\mathrm{Pr}$, $\mathrm{R} 1=\mathrm{CH}_{3}, \mathrm{R} 2=\mathrm{Ph} ; 4-\mathrm{R}=\mathrm{i}-\mathrm{Pr}, \mathrm{R} 1=$ $\mathrm{CH}_{3}, \mathrm{R} 2=4-\mathrm{NO}_{2}-\mathrm{C}_{6} \mathrm{H}_{4}$;

Scheme 1. Synthesis of 1,3-benzoxazines derivatives

Scheme 2. Synthesis of 2-[5-(4-Nitrophenyl)-1 H-pyrazol-3yl]phenol 5 
Table 1. Microbial strains and cell lines.

\begin{tabular}{l|l|l|l|l|l}
\hline Abbreviation & \multicolumn{1}{|c|}{ Name } & \multicolumn{1}{c|}{ Description } & \multicolumn{1}{c}{ Strain } & \multicolumn{1}{c}{ Organsim } & \multicolumn{1}{c}{ Type } \\
\hline $\mathrm{Sa}$ & Staphylococcus aureus & MRSA & ATCC 43300 & Bacteria & G+ve \\
\hline $\mathrm{Ec}$ & Escherichia coli & FDA control & ATCC 25922 & Bacteria & G-ve \\
\hline $\mathrm{Kp}$ & Klebsiella pneumoniae & MDR & ATCC 700603 & Bacteria & G-ve \\
\hline $\mathrm{Ab}$ & Acinetobacter baumannii & Type strain & ATCC 19606 & Bacteria & G-ve \\
\hline $\mathrm{Pa}$ & Pseudomonas aeruginosa & Type strain & ATCC 27853 & Bacteria & G-ve \\
\hline $\mathrm{Ca}$ & Candida albicans & CLSI reference & ATCC 90028 & Fungi & Yeast \\
\hline $\mathrm{Cn}$ & Cryptococcus neoformans var. grubii & H99 - Type strain & ATCC 208821 & Fungi & Yeast \\
\hline
\end{tabular}

fungus strains was studied by the microbial growth inhibition assay.

The data on the tested strains of microorganisms are given in Table 1.

Table 2. The percentage of growth inhibition of whole cells by synthesized compounds

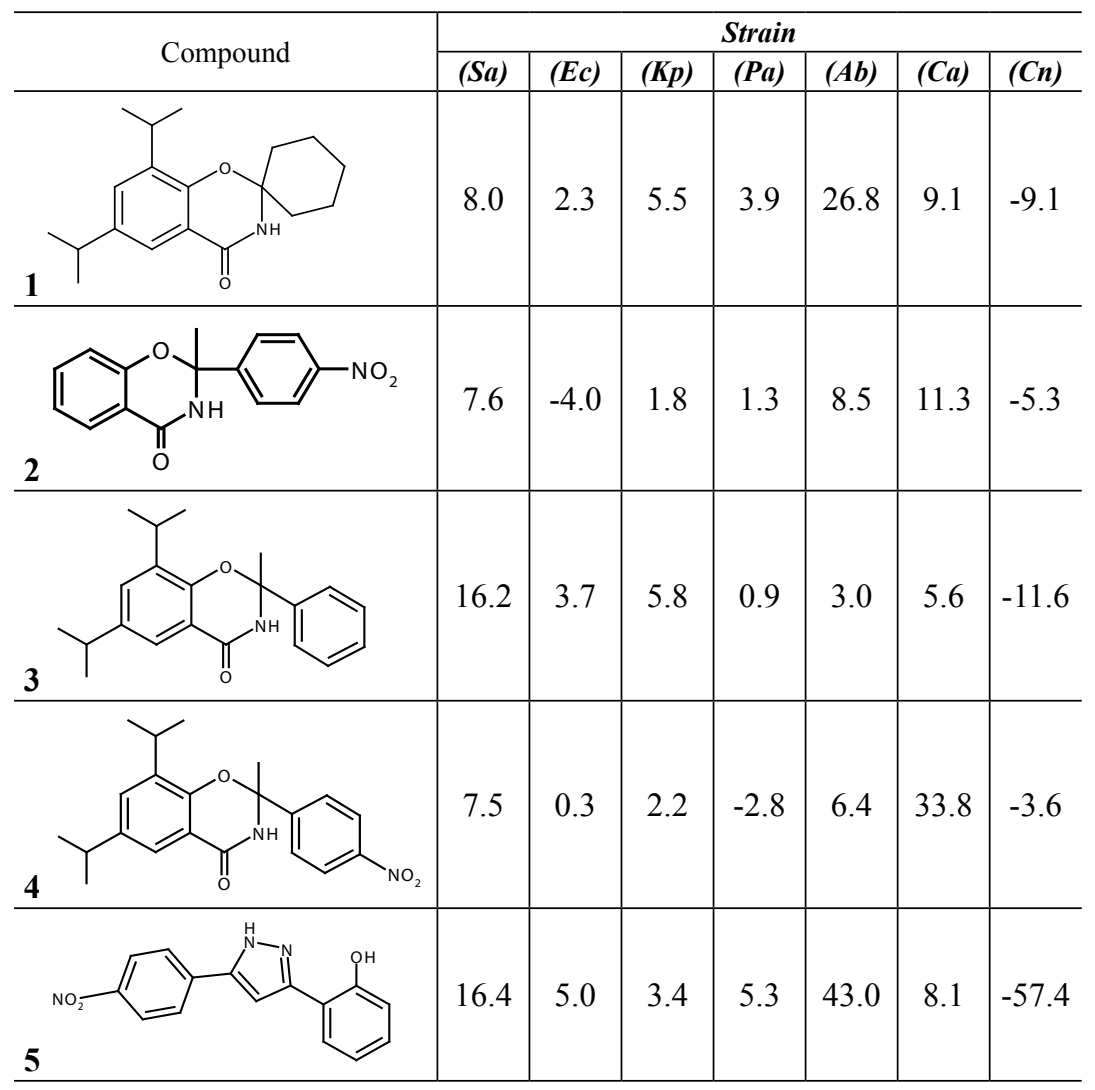

The screening is performed as two replica $(\mathrm{n}=2)$, with both replicas on different assay plates, but from single plating and performed in a single screening experiment (microbial incubation). Each individual value is reported in the Tables (see 2 and 3).

During the analysis of the results obtained, it was found that among the synthesized compounds the most active with respect to Acinetobacter baumannii were the compounds (5) and (1) (Table 2 and Figure 1).

The repeated experiment confirmed the activity of compounds numbered (5) and (1) with regard to the Acinetobacter baumannii strain, as well as the activity of compound (4) in relation to the Candida albicans fungus (Table 3 and Figure 2).

Conclusions. According to the results of in vitro biological testing, it has been shown that the highest activity among the synthesized compounds 


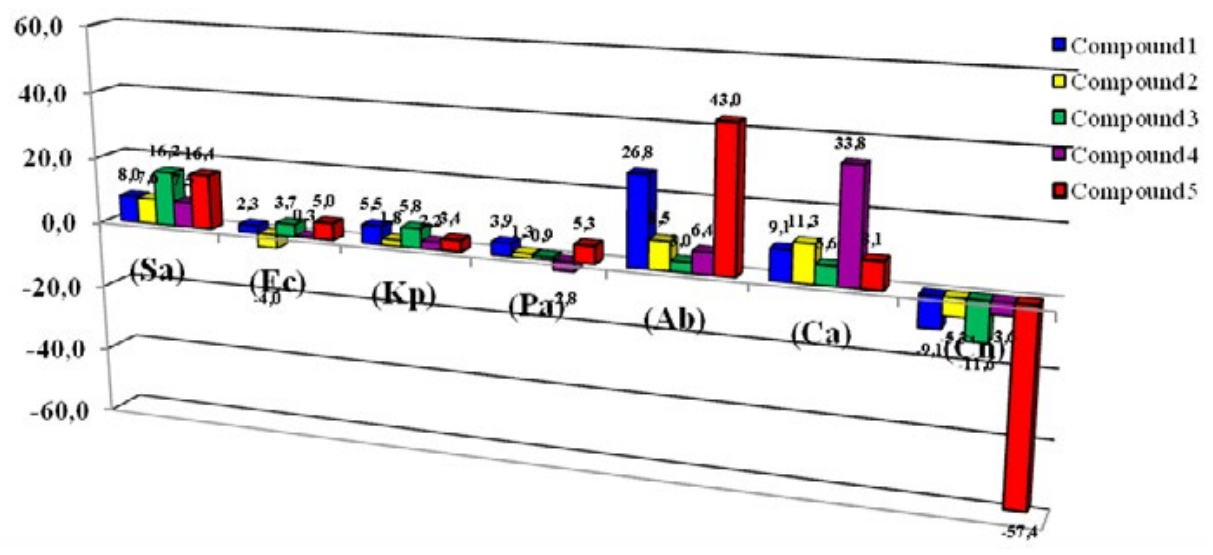

Fig. 1. Graph of growth inhibition of whole cells microorganisms by synthesized compounds (заменить запятые точками в графике) with respect to Acinetobacter baumannii had the compounds 2-[5-(4-nitrophenyl)-1H-pyrazol-3-yl]phenol (5) and 6,8-diisopropylspiro[1,3-benzoxazine-2,1'-cyclohexan]$4(3 H)$-one (1), in concentration of $32 \mu \mathrm{g} / \mathrm{ml}$ (43\% and $27 \%$, respectively). Compound (4), 6,8-diisopropyl-2-methyl-2-(4-nitrophenyl)2,3-dihydro-4H-1,3-benzoxazine-4-one, has shown the fungicidal activity against the Candida albicans strain.

\section{Acknowledgements}

The authors thank Prof. Sergii Yarmoluk from the Institute of Molecular Biology and Genetics NAS of Ukraine for the help in organization of antimicrobial screening.

Antimicrobial screening was conducted by CO-ADD (The Community for Antimicrobial Drug Discovery), Wellcome Trust (UK) and the University of Queensland (Australia).

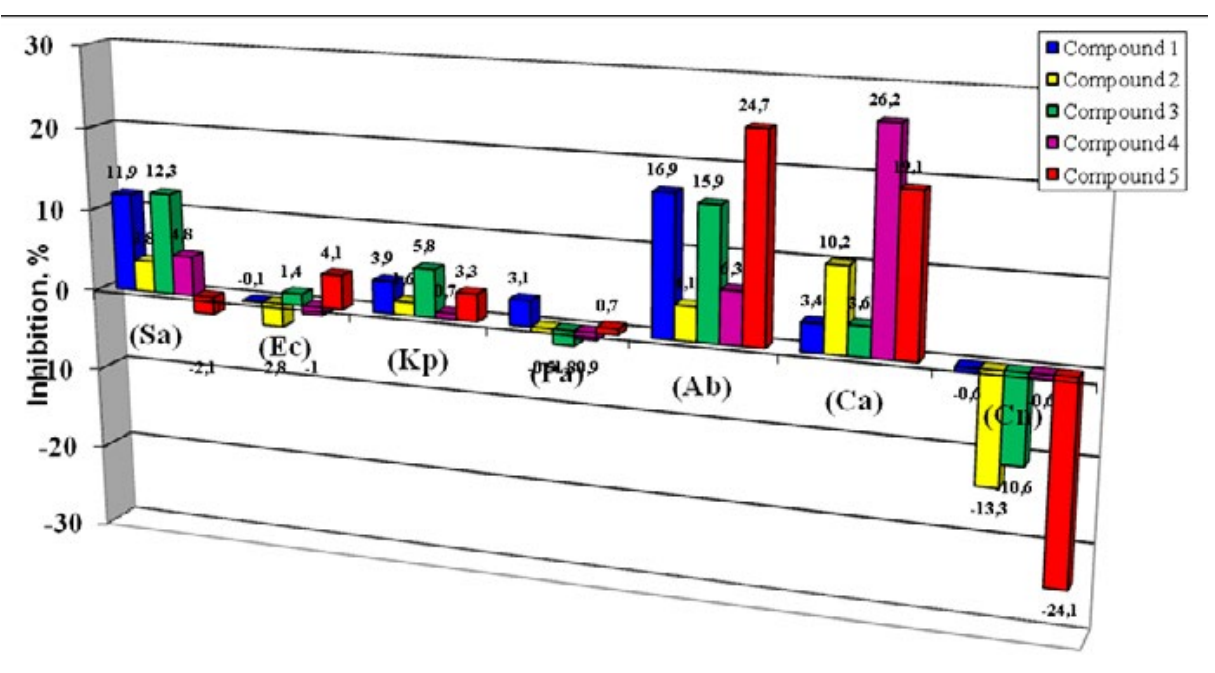

Fig. 2. Graph of growth inhibition of whole cells microorganisms by synthesized compounds (заменить запятые точками в графике) 
Table 3. The percentage of growth inhibition of whole cells by synthesized compounds

\begin{tabular}{|c|c|c|c|c|c|c|c|}
\hline \multirow{2}{*}{ Compound } & \multicolumn{7}{|c|}{ Strain } \\
\hline & $(\mathrm{Sa})$ & $(E c)$ & $(K p)$ & $(P a)$ & $(A b)$ & $(\mathrm{Ca})$ & $(\mathrm{Cn})$ \\
\hline & 11,9 & $-0,1$ & 3,9 & 3,1 & 16,9 & 3,4 & $-0,6$ \\
\hline & 3,8 & $-2,8$ & 1,6 & $-0,5$ & 4,1 & 10,2 & $-13,3$ \\
\hline & 12,3 & 1,4 & 5,8 & $-1,8$ & 15,9 & 3,6 & $-10,6$ \\
\hline & 4,8 & -1 & 0,7 & $-0,9$ & 6,3 & 26,2 & $-0,6$ \\
\hline & $-2,1$ & 4,1 & 3,3 & 0,7 & 24,7 & 19,1 & $-24,1$ \\
\hline 5 & & & & & & & \\
\hline
\end{tabular}

4. Zhang Z, Olland AM, Zhu Y, Cohen J, Berrodin T, Chippari $S$, Appavu C, Li S, Wilhem J, Chopra R, Fensome A, Zhang P, Wrobel J, Unwalla RJ, Lyttle CR, Winneker $R C$. Molecular and pharmacological properties of a potent and selective novel nonsteroidal progesterone receptor agonist tanaproget. $J$ Biol Chem. 2005;280(31):28468-75.

5. Charmantray F, Demeunynck $M$, Carrez D, Croisy A, Lansiaux A, Bailly C, Colson P. 4-Hydroxymethyl-3-aminoacridine derivatives as a new family of anticancer agents. J Med Chem. 2003; 46(6):967-77.

6. Gala F, Dauria MV, De Marino S, Sepe V, Zollo F, Smith CD, Keller SN, Zampella A. Jaspamide M-P: new tryptophan modified jaspamide derivatives from the sponge Jaspis splendans. Tetrahedron. 2009; 65(1): 51-6.

7. Wang $\mathrm{CF}$, Su YC, Kuo SW, Huang CF, Sheen YC, Chang FC. Low-surface-free-energy materials based on polybenzoxazines. Angew

\section{REFERENCE}

1. Saito T, Ogawa S, Takei N, Kutsumura N, Otani T. Palladium-catalyzed highly regio- and stereoselective synthesis of 4-alkylidene-4H-3,1-benzoxazines from N-acyl-o-alkynylanilines. Org Lett. 2011; 13(5):1098-101.

2. Ilić M, Ilaš J, Dunkel P, Mátyus P, Boháč A, Liekens $S$, Kikelj $D$. Novel 1,4-benzoxazine and 1,4-benzodioxine inhibitors of angiogenesis. Eur $J$ Med Chem. 2012;58:160-70.

3. Zhang P, Terefenko EA, Fensome A, Zhang Z, Zhu Y, Cohen J, Winneker R, Wrobel J, Yardley J. Potent nonsteroidal progesterone receptor agonists: synthesis and SAR study of 6-aryl benzoxazines. Bioorg Med Chem Lett. 2002;12(5):787-90.
Chem Int Ed Engl. 2006;45(14):2248-51.

8. Lin CH, Cai SX, Leu TS, Hwang TY, Lee HH. Synthesis and Properties of Flame-Retardant Benzoxazines by Three Approaches. J Polym Sci A. 2006; 44(11): 3454-68.

9. Ishida $H$, Ohba $S$. Synthesis and characterization of maleimide and norbornene functionalized benzoxazines. Polymer. 2005; 46(15): 5588-95.

10. Burke WJ. 3,4-Dihydro-1,3,2H-Benzoxazines. Reaction of p-substituted phenols with $\mathrm{N}, \mathrm{N}$-dimethylolamines. J Am Chem Soc. 1999; 71(2): 609-12.

11. Farat OK, Markov VI, Varenichenko SA, Dotsenko VV, Mazepa $A V$. The Vilsmeier-Haack formylation of 2,3-dihydro-4H-1,3-benzoxazin-4-ones and isomeric 1,2-dihydro-4H-3,1-benzoxazin-4-ones: an effective ap-proach to functionalized $2 \mathrm{H}-/ 4 \mathrm{H}-$ 
chromenes and tetrahydroacridines. Tetrahedron. 2015; 71(34): 5554-61.

12. Zahorulko SP, Varenichenko SA, Farat OK, Mazepa AV, Okovytyy SI, Markov VI. Reactions of $2 \mathrm{H}(4 \mathrm{H})$-chromenes with dinucleophiles: one-step synthesis of 2-(1H-(bi)pyrazol-3-yl)- and 2-(1,4(5)-(benzo)diazepin-4-yl)phenols. Chem Heterocycl Comp. 2018; 54(9):859-67.

13. Gaulton A, Bellis LJ, Bento AP, Chambers J, Davies $M$, Hersey A, Light $Y$, McGlinchey $S$, Michalovich D, Al-Lazikani B, Overington JP. ChEMBL: a large-scale bioactivity database for drug discovery. Nucleic Acids Res. 2012;40(Database issue):D1100-7.

14. Wishart DS, Knox C, Guo AC, Cheng D, Shrivastava S, Tzur D, Gautam B, Hassanali M. DrugBank: a knowledgebase for drugs, drug actions and drug targets. Nucleic Acids Res. 2008;36(Database issue):D901-6.

\section{Дослідження антимікробної активності похідних 1,3-бензоксазину}

С.П. Загорулько, С.А. Варениченко, О.К. Фарат, I.В. Маркова, В.І. Марков

Мета. Дослідити наявність антимікробної активності серед похідних 1,3-бензоксазинів. Методи. Синтез, антимікробний скринінг, біохімічне тестування in vitro. Результати. Для антимікробного скринінгу вибиралися сполуки які відрізняються від досліджених на 30 \%. Було відібрано 5 сполук і проведено дослідження ї антимікробної активності проти п'яти бактерій та двох грибів методами аналізу інгібування росту цілих клітин. Інгібування росту індивідуального зразка розраховувався у відсотках на основі негативних контролів (лише середовищ) та позитивних контролів (бактеріальних / грибкових середовищ без інгібіторів). У ході аналізу отриманих результатів було встановлено що найбільшу активність серед синтезованих сполук проявили по відношенню до Acinetobacter baumannii сполуки - 2-[5-(4-нітрофеніл)-1H-піразол-3-іл]фенол та 6,8-діізопропілспіро[1,3-бензоксазін-2,1'-циклогексан]4(3H)-он $43 \%$ та 27 \% при концентрації 32 мкг/мл. Фунгіцидну активність щодо штаму Candida albicans проявила сполука - 6,8-діізопропіл-2-метил-2-(4нітрофеніл)-2,3-дигідро-4H-1,3-бензоксазин-4-он.
Висновки. Похідні 1,3-бензоксазинів проявляють помірну антимікробну активність, що дозволяє рекомендувати продовження пошуку ефективних протимікробних засобів серед даного класу сполук, у тому числі і завдяки цілеспрямованому синтезу нових сполук 3 прогнозованими протимікробними властивостями.

Ключ ов і сл ов а: похідні 1,3-бензоксазинів, $1 H$-піразол-3-іл-фенол, антимікробний скринінг.

\section{Исследование антимикробной активности производных 1,3-бензоксазинов}

С. П. Загорулько, С. А. Варениченко, О. К. Фарат, И. В. Маркова, В. И. Марков

Цель. Исследовать наличие антимикробной активности среди производных 1,3-бензоксазинов. Методы. Синтез, антимикробный скрининг, биохимическое тестирование in vitro. Результаты. Для антимикробного скрининга отбирали соединения, которые отличаются от изученных на $30 \%$. Было отобрано 5 соединений и проведено исследование их антимикробной активности против пяти бактерий и двух грибов методами анализа ингибирования роста целых клеток. Ингибирование роста индивидуального образца рассчитывается в процентах на основании отрицательных контролей (только среда) и положительных контролей (бактериальной / грибковой среды без ингибиторов). В ходе анализа полученных результатов було установлено что наибольшую активность среди синтезированных соединений проявили по отношению к Acinetobacter baumannii соединения - 2-[5-(4-нитрофенил)-1Н-пиразол-3-ил] фенол и 6,8-диизопропилспиро[1,3-бензоксазин-2,1'-циклогексан]-4(3H)-он 43 \% и 27 \% при концентрации 32 мкг/мл. Фунгицидную активность против штамма Candida albicans проявило соединение - 6,8-диизопропил-2-метил-2-(4-нитрофенил)-2,3-дигидро-4H-1,3бензоксазин-4-он. Выводы. Производные 1,3-бензоксазинов проявили умеренную антимикробную активность, что позволяет рекомендовать продолжение поиска эффективных противомикробных средств среди данного класса соединений, в том числе и благодаря целенаправленному синтезу новых соединений с прогнозироваными противомикробными свойствами.

Received 20.02.2019 